\title{
GAP Bölgesi'nde Pestisit Satış Yerlerinde Çalışanlarda Kolinesteraz İnhibitörleri ve Karaciğer Enzim Düzeylerinin İncelenmesi
}

\author{
Fatma MUTLU1* ${ }^{*}$, Zeynep ŞiMŞEK², Mehmet Cici ${ }^{3}$ \\ ${ }^{1}$ Harran Üniversitesi, Fen Bilimleri Enstitüsü, Şanlıurfa, Türkiye. \\ ${ }^{2}$ Harran Üniversitesi, Tıp Fakültesi, Halk Sağlığı Anabilim Dalı, Şanlıurfa, Türkiye. \\ ${ }^{3}$ Harran Üniversitesi, Mühendislik Fakültesi, Çevre Mühendisliği Bölümü, Şanlıurfa, Türkiye.
}

Geliş Tarihi: 17.12.2016

Kabul Tarihi: 27.12.2016

\begin{abstract}
Özet: Pestisitler, zararlılara karşı kullanılan doğal veya sentetik kimyasal maddelerdir. Kimyasal pestisitler, nüfus artışına paralel olarak artan gıda ihtiyacını karşılamak için dünyanın her yerinde tarım zararlılarıyla mücadele için kullanımı hızla artan maddelerdir. Pestisitlerin bilinen etkilerinden biri karboksilik esteraz yapısındaki enzimleri inhibe etmeleridir. Bu enzimler, vücudun normal fonksiyonlarının sürdürülmesi için gerekli olan asetilkolinin parçalanmasında rol alırlar. Asetilkolinesterazın inhibisyonu ise bütün kolinerjik sinaps ve kavşaklarda asetilkolin birikmesine neden olur. Böylece uzun dönemde pestisit etkilenimi, depresyon, hafıza bozukluğu, uyku bozukluğu, halsizlik, halüsinasyon görme gibi çeşitli rahatsızlıkları ortaya çıkarabilmektedir. Oldukça toksik kimyasal maddeler olan pestisitlerin kullanımındaki artış, toplumun etkilenme riskini de arttırmaktadır. Özellikle uygulamayı yapan kişilerin maruziyetleri üzerine yapılmış çalışmalar bulunmakla birlikte, satış yerlerinde çalışanlar üzerindeki sağlık etkilerine dair çalışmalar sınırlı düzeydedir. Pestisit satış yerlerinin artışına paralel olarak, uygulayan kişilerin yanı sıra bunların muhafazasını ve satışını yapan kişilerin de bu maddelerden etkilenim düzeylerini belirlemek önemlidir. Bu araştırmada, pestisit satışı yapılan yerlerde çalışanların etkileniş düzeylerini belirlemek amaçlanmıştır. GAP illerinin Gıda Tarım ve Hayvancılık İ Müdürlükleri'nden temin edilen bayi listesinden örneklem seçimi yapılarak 399 kişiye soru formu uygulanmış ve 10 cc kan örneği alınmıştır. Kanlar santrifüj edildikten sonra, serumda bazı biyokimyasal parametrelere bakılmıştır. Pestisitlerin karaciğer fonksiyonlarına etkileri ile ilgili olarak elde edilen sonuçlar örneklemde yer alan işçilerin pestisitlerden olumsuz yönde etkilendiklerini göstermektedir. Pestisitlerle doğrudan temasta olan tarım ilacı satış bayilerinde çalışanlar, periyodik olarak kan testlerinden geçirilip kolinesteraz düzeyleri sürekli kontrol altında tutulmalı, normalin altındaki enzim düzeylerinde bir süre ortamdan uzak kalmaları sağlanmalı ve çalışma koşulları düzeltilmelidir.
\end{abstract}

Anahtar Kelimeler: Karaciğer enzimleri, Kolinesteraz inhibitörleri, Pestisit, Tarım ilacı bayii.

\section{Investigation of Cholinesterase Inhibitors and Liver Enzyme Levels in Pesticide Dealer Workers of}

\section{GAP Region}

\begin{abstract}
Pesticides are natural or synthetic chemicals that are used for pest control. The use of chemical pesticides is increasing worldwide in parallel with the population growth and increasing food needs. One of the known effects of pesticides is the inhibition of enzymes in the composition of carboxylic esterase. These enzymes take role in decomposing the acetylcholine which is needed for sustaining normal body functions. The inhibition of acetylcholine causes its build up in all cholinergic synapses. Thus, pesticide influence may lead to depression, memory impairment, sleeping disorders, weakness, and hallucinations in the long term. The increase in use of pesticides which are quite toxic also raises the risk for public. Although there are studies on especially the exposure of practicing personnel, the studies of the health effects on personnel working in pesticide dealers are very limited. In parallel with the increase in number of pesticide dealers, it is important to investigate the exposure levels by these chemicals on workers that are responsible for the sale and storage of these materials. This study aims to determine the exposure levels of pesticide dealer workers. The list of dealers was obtained from the city directorates of GAP cities of Ministry of Food and Agriculture and used for selecting the 399 samples from whom $10 \mathrm{cc}$ blood samples were taken. Some biochemical parameters were investigated after centrifuging the blood samples. The results show that there are effects on liver functions of workers included in the sample as a result of pesticide exposure. The workers who are in directly contact with pesticides should be periodically tested for cholinesterase levels and be continuously placed under control, the workers who have sub-normal enzyme levels should be removed from the work environment for a period and their working conditions should be recovered.

Keywords: Cholinesterase inhibitors, Liver enzymes, Pesticides, Pesticide dealer.
\end{abstract}

\section{Giriş}

Tarım kimyasalları, besinleri, pestisitleri, petrol ürünlerini, gübreleri, bitki büyüme düzenleyicilerini ve veteriner ilaçlarını içeren pek çok formülden oluşur. Bu kimyasallar çeşitli formlarda (granül, toz gibi küçük parçacıklar veya blok şeklinde katı olarak) kullanılır. Ayrıca aeresol, sıvı, gaz olarak da uygulanabilir (Ridgway ve ark., 1978). Pestisitler, zararlılara karşı kullanılan doğal veya sentetik 
kimyasal maddelerdir. Kimyasal pestisitler, nüfus artışına paralel olarak artan gıda ihtiyacını karşılamak için dünyanın her yerinde tarım zararlılarıyla mücadele için kullanımı hızla artan maddelerdir. Pestisitlerin tarımdaki faydasının yanında, güvenli pestisit depolama ve uygulamaların yetersiz olduğu ülkelerde yabani yaşam, toprak, su, çevre ve insan sağlığı üzerinde zararlı etkileri bildirilmiştir. Bu nedenle zararlılarla mücadelede en son tercih edilmesi gereken maddelerdir. Tarımda uygulanan pestisitlerin sadece $\% 10^{\prime} u$ hedeflenen organizmaya ulaşmakta, kalan miktarı ise su, toprak, hava ve çevreye yayılarak halk sağlığını etkilemekte ve hedef olmayan organizmalarda da zarara yol açmaktadır (Butinof ve ark., 2015).

Pestisitler, oldukça toksik kimyasal maddeler olup, bilinen etkilerinden biri karboksilikesteraz yapısındaki enzimleri inhibe etmeleridir. Asetilkolinesteraz ve psedokolinesteraz sinir sisteminin sağlıklı çalışması için gerekli iki önemli enzimdir. Asetilkolin sinirler arasında ve sinirlerden kaslara iletimi sağlar. Asetilkolin salındıktan sonra temizlenmesi gerekir yoksa ileti devam eder bu işi asetilkolinesteraz ve psedokolinesteraz yapar. Sinirler arasına sinyallerin düzgün iletilmesi için bu iki enzim gereklidir. Asetilkolinesteraz hem sinir hem de kırmızı kan hücrelerinde bulunurken, psedokolinesteraz ise sadece karaciğer hücrelerinde bulunur (Vural, 2005). Genellikle organik fosforlu bileşikler insektisit olarak kullanımaktadır. Fosfor atomuna çifte bağ ile oksijen bağlanmışsa fosfatlar, sülfür bağlanmışsa tiyofosfatlar denir. Organik fosforlu bileşikler, toksisitelerini asetil kolinesteraz enzimini inhibe ederek gösterirler. Direkt etkili ve indirekt etkili olarak ikiye ayrılırlar. Direkt etkililer $\mathrm{P}=\mathrm{O}$ yapısında oldukları için aktivasyona gereksinimleri olmadan direkt kolinesterazı inhibe ederler. Indirekt etkililer $\mathrm{P}=\mathrm{S}$ ihtiva eden kimyasallardır. Bu sebeple tiyoester $(P=S)$ bağı içeren ilaçların etki mekanizmaları $\mathrm{P}=\mathrm{O}^{\prime}$ ya dönüşümü ile aktivasyona uğrayarak asetilkolinesterazı inhibe etmeleri şeklinde olur. Asetilkolinesterazın inhibisyonu bütün kolinerjik sinaps ve kavşaklarda asetilkolin birikmesine neden olur. Uzun dönemde pestisit etkilenimi depresyon, hafıza bozukluğu, uyku bozukluğu, halsizlik, halüsinasyon görme gibi çeşitli rahatsızlıklar ortaya çıkarabilmektedir (Duydu, 2009). Pestisitlere uzun süre maruz kalan tarım işçilerinin karaciğer fonksiyonlarına bakılmış ve pestisitlere doğrudan maruziyeti olmayan kişilerle kıyaslandığında; bu kişilerde protein düzeyleri anlamlı bir şekilde azalırken, AST, ALT, ALP ve LDH değerlerinde kontrol grubuna göre anlamlı bir artış gözlemlenmiştir (Çömelekoğlu ve ark., 2000).

İçel'de yapılan bir çalışmada, tarım alanında çalışan kişilerin plazmalarında kolinesteraz enziminin aktivite değişimine bakılmış ve kontrol grubu ile karşılaştırıldığında kolinesteraz enzim düzeylerinde \%24.71 oranında düşüş olduğu tespit edilmiştir (Zeren ve ark., 1998). Tunus'da yapılan bir çalışmada, tarımla uğraşan kişilerdeki biyokimyasal ve hematolojik bulguları üzerine pestisitlerin etkileri incelenmiş ve uzun dönemde pestisite maruziyetin, butiril-kolinesteraz enzimini inhibe ederek damar ve metabolik hastalıklarının gelişimine imkân sağladığı görülmüştür (Wafa ve ark., 2013). Dünya Sağlık Örgütü tarafından 1992 yılında yapılan bir araştırmaya göre her yıl dünyamızda 3 milyon zehirlenme olayının yaşandığı ve 220000 ölümün gerçekleştiği ortaya konulmuştur (WHO, 1992). Gelecekteki 50 sene içinde yeryüzünde pestisit kullanımında azalma olmayacağı, bilakis artış olacağı öngörülmektedir. Sıcaklıkların artması sebebiyle ürün verimindeki azalmalardan dolayı elimizdeki ürün mevcudiyetini koruyabilmek için daha fazla pestisit kullanmamı gerekeceği tahmin edilmektedir (Miraglyi ve ark., 2009.).

Birçok pestisitin, yararı yanında, insanlara, hayvan ve çevreye zararı dokunmaktadır. 1970'li yılların başından itibaren yapılmaya başlanılan çalışmaların sonucunda Kalıcı Organik Kirleticiler (KOK) diye isimlendirilen tarım ilaçları (aldrin, endrin, toksafen, klordan, dieldrin, heptakol, mireks, DDT, heksaklorobenzen ve pentaklorobenzen) bir takım durumlar haricinde kullanımdan kaldırılmış, ayrıca mevcut stoklar da izlenmeye alınmıştır (CFGI, 2013). Antibiyotiklerde olduğu gibi pestisitler de gelişigüzel, kontrolsüz kullanılmaktadır (Demirdöğen, 2010). Pestisitler tek başına kullanıldığında zehirli olmasının yanısıra parçalanarak daha da zehirli yeni maddelerin oluşmasına sebebiyet vermektedirler (Tülüce ve ark., 2002). Pestisit satış yerlerinin artışına paralel olarak, uygulayan kişilerin yanı sıra bunların muhafazasını ve satışını yapan kişilerin de bu maddelerden etkilenim düzeylerini belirlemek önemlidir. Bu araştırmada, pestisit satışı yapılan yerlerde çalışanların etkilenimlerini belirlemek amaçlanmıştır.

\section{Materyal ve Metot}

GAP illerinin Gıda Tarım ve Hayvancılık il Müdürlükleri'nden tarım ilacı satan bayi listesi alınmış, örnek seçimi yapılarak 399 kişi ziyaret edilerek yüz yüze görüşme yöntemiyle yaş, cinsiyet, öğrenim durumu, çalışma süresi, sağlık yakınmalarından oluşan soru formu uygulanmış ve $10 \mathrm{cc}$ kan alınmıştır. Serumlarda karaciğer hasarını belirlemek için sıklıkla kullanılan enzimlerden aminotranferazların [aspartat amino transferaz (AST-SGOT) ve alanin amino transferaz (ALT-SGPT)] düzeyi, asetilkolinesteraz (AChE) enzim düzeyi, alkalen fosfataz (ALP), total protein (T.Protein), albümin 
(ALB) ve laktat dehidrogenez (LDH) enzim düzeylerine spektrofotometrik metotla bakılmıştır. Elde ettiğimiz bulgular standart değerlerle karşılaştırılarak enzim düzeyleri değerlendirilmiştir. Çalışanlara ait verilerden, SPSS 15.0 veri giriş ve analiz programında veri tabanı oluşturularak, anketlerin ve laboratuar çalışmalarının sonuçları girilmiş ve biyoistatistiksel analizler yapılarak tablolar oluşturulmuştur. Bağımsız gruplarda oranların karşılaştırılmasında Pearson'un Ki-Kare testi uygulanmıştır.

\section{Bulgular}

Çalışmaya katılan 399 kişinin \%98.2'si erkek, \%1.8'i kadın olup yaş gruplarına göre dağılımı, \%4.3'ü 19 ve altında, \%21.3'ü 20-29, \%36.3'ü 30-39, \%23.1'i 40-49 yaşları arasında olup, yaklaşık \%14'ü 50 yaş ve üzerindedir (Tablo 1).Çalışmaya katılanların \%10.3'ü ilkokula gitmemiş, \%13.5' $\mathrm{i}$ ilkokul terk, \%34.1'i ilkokul 1. kademe, \%11.5'i ilkokul 2. kademe, \%9.0'u lise mezunu, \%20.8'i üniversite mezunudur. Bu kişilerin içinde en büyük grubu \%44.9 oranıyla 1-9 yıl çalışanlar, sonraki büyük grubu da 1 yıldan az çalışanlar oluşturmaktadır. Tablo 2'de pestisit satış yerlerinde çalışanların bazı enzim düzeyleri çalışma sürelerine göre incelendiğinde; AST ortalama değeri istatistiksel olarak farklılık göstermemesine rağmen $(P>0.05)$ ALT, TPROT, ALB, LDH ve AChE değerleri istatistiksel olarak farklılık göstermektedir $(P<0.05)$. Tablo 3'te satış yerinde açıkta ürün bulunma durumuna göre enzim ortalama değerleri verilmiştir
$A L T, A L P$ ve $L D H$ değerleri açıkta ürün bulunma durumuna göre istatistiksel olarak farklılık gösterirken $(P<0.05)$, diğer enzimlerde istatistiksel farklılık saptanmamıştır ( $>0.05)$. Tablo 4'te satış yerinde muhafazalı oda bulunma durumuna göre enzim ortalama değerleri verilmiştir. ALT ve ALB değerleri muhafazalı oda bulunma durumuna göre istatistiksel olarak farklılık gösterirken $(P<0.05)$, diğer enzimlerde istatistiksel olarak farklılık saptanmamıştır ( $P>0.05)$. Tablo 5 'de satış yerinde havalandırma düzeni bulunma durumuna göre enzim ortalama değerleri verilmiştir. ALT, TPROT, $A L B$ ve $L D H$ değerleri havalandırma düzeni bulunma durumuna göre istatistiksel farklılık gösterirken $(P<0.05)$, diğer enzimlerde istatistiksel olarak farklılık saptanmamıştır ( $P>0.05)$. Tablo 6'da satış yerlerinde çalışanların pestisit uygulamasında da çalışma durumuna göre, AST ve TPROT değerleri istatistiksel farklılık gösterirken $(P<0.05)$, diğer enzimlerde istatistiksel olarak farklılık saptanmamıştır $(\mathrm{P}>0.05)$.

Tablo 1. Pestisit Satış Yerlerinde Çalışanların Yaş Gruplarına Göre Dağııımı

\begin{tabular}{lcc}
\hline Yaş grupları, Yıl & Sayı & $\%$ \\
\hline $\mathbf{1 9}$ ve altı & 17 & 4.3 \\
$\mathbf{2 0 - 2 9}$ & 85 & 21.3 \\
$\mathbf{3 0 - 3 9}$ & 145 & 36.3 \\
$\mathbf{4 0 - 4 9}$ & 92 & 23.1 \\
$\mathbf{5 0 - 5 9}$ & 36 & 9.0 \\
$\mathbf{6 0}$ ve üzeri & 18 & 4.5 \\
Cevapsız & 6 & 1.5 \\
\hline Toplam & $\mathbf{3 9 9}$ & $\mathbf{1 0 0 . 0}$ \\
\hline
\end{tabular}

Tablo 2. Pestisit satış yerlerinde çalışanların çalışma sürelerine göre enzim düzeylerinin dağılımı

\begin{tabular}{lccccccc}
\hline Çalışma Süresi & AST & ALT & ALP & TPROT & ALB & LDH & AChE \\
\hline 1 Yıldan az & $17.4 \pm 8.9$ & $13.8 \pm 8.4$ & $78.5 \pm 36.6$ & $7.3 \pm 0.7$ & $4.2 \pm 0.4$ & $274.4 \pm 226.2$ & $9648.6 \pm 2280.1$ \\
1-9 Yıl & $18.9 \pm 8.5$ & $21.5 \pm 14.0$ & $68.7 \pm 22.5$ & $6.5 \pm 0.7$ & $3.7 \pm 0.4$ & $216.2 \pm 153.1$ & $10046.4 \pm 2501.5$ \\
10 Yıl ve üzeri & $19.7 \pm 9.0$ & $27.6 \pm 16.9$ & $66.6 \pm 14.0$ & $6.4 \pm 0.5$ & $3.5 \pm 0.4$ & $176.7 \pm 34.4$ & $10783.9 \pm 2540.9$ \\
\hline F Değeri & 1.795 & 28.950 & 6.226 & 58.563 & 88.965 & 7.648 & 4.475 \\
P Değeri & 0.167 & 0.0001 & 0.002 & 0.0001 & 0.0001 & 0.001 & 0.012 \\
\hline
\end{tabular}

Tablo 3. Pestisit satış yerlerinde açıkta ürün satışı durumuna göre enzim düzeylerinin dağıımı

\begin{tabular}{lccccccc}
\hline $\begin{array}{l}\text { Açıta Ürün } \\
\text { Satılma Durumu }\end{array}$ & AST & ALT & ALP & TPROT & ALB & LDH & AChE \\
\hline Evet & $18.3 \pm 8.6$ & $14.7 \pm 9.0$ & $64.6 \pm 18.7$ & $6.9 \pm 0.9$ & $3.9 \pm 0.4$ & $310.6 \pm 255.5$ & $9354.8 \pm 2096.3$ \\
Hayır & $18.3 \pm 9.3$ & $19.3 \pm 14.0$ & $6.9 \pm 0.8$ & $3.9 \pm 0.4$ & $3.9 \pm 0.5$ & $231.4 \pm 181.7$ & $10051.5 \pm 2458.5$ \\
\hline T Değeri & -0.003 & -2.241 & -2.340 & -0.363 & -0.368 & 2.621 & -1.865 \\
P Değeri & 0.997 & 0.026 & 0.020 & 0.717 & 0.713 & 0.009 & 0.063 \\
\hline
\end{tabular}


Tablo 4. Pestisit satış yerlerinde muhafazalı oda olma durumuna göre enzim düzeylerinin dağıımı

\begin{tabular}{lccccccc}
\hline $\begin{array}{l}\text { Muhafazalı } \\
\text { Oda Durumu }\end{array}$ & AST & ALT & ALP & TPROT & ALB & LDH & \multirow{2}{*}{ AChE } \\
\hline Evet & $18.3 \pm 9.6$ & $17.9 \pm 12.9$ & $71.3 \pm 22.9$ & $6.9 \pm 0.8$ & $4.0 \pm 0.5$ & $247.9 \pm 200.8$ & $9887.4 \pm 2447.7$ \\
Hayır & $18.4 \pm 7.4$ & $21.7 \pm 15.2$ & $76.4 \pm 34.2$ & $6.7 \pm 0.7$ & $3.8 \pm 0.5$ & $222.3 \pm 166.1$ & $10212.9 \pm 2274.3$ \\
\hline T Değeri & -0.083 & -2.105 & -1.487 & 1.797 & 2.061 & 0.996 & -1.019 \\
P Değeri & 0.934 & 0.036 & 0.138 & 0.073 & 0.040 & 0.320 & 0.309 \\
\hline
\end{tabular}

Tablo 5. Pestisit satış yerlerinde havalandırma düzeni bulunma durumuna göre dağılımı

\begin{tabular}{lccccccc}
\hline $\begin{array}{l}\text { Havalandırma } \\
\text { Düzeni }\end{array}$ & AST & ALT & ALP & TPROT & ALB & LDH & AChE \\
\hline Evet & $18.1 \pm 10.2$ & $16.3 \pm 12.1$ & $73.4 \pm 28.0$ & $7.1 \pm 0.8$ & $4.1 \pm 0.5$ & $263.1 \pm 224.1$ & $9791.5 \pm 2493.8$ \\
Hayır & $18.7 \pm 7.7$ & $21.9 \pm 14.6$ & $71.6 \pm 23.1$ & $6.7 \pm 0.7$ & $3.8 \pm 0.5$ & $214.6 \pm 143.6$ & $10213 \pm 2308.6$ \\
\hline T Değeri & -0.635 & -3.775 & 0.609 & 4.973 & 6.085 & 2.233 & -1.559 \\
P Değeri & 0.934 & 0.0001 & 0.543 & 0.001 & 0.0001 & 0.026 & 0.312 \\
\hline
\end{tabular}

Tablo 6. Pestisit satış yerlerinde çalışanların pestisit uygulamasında çalışma durumuna göre enzim düzeylerinin dağııımı

\begin{tabular}{lccccccc}
\hline $\begin{array}{l}\text { Pestisit Uygulama } \\
\text { Durumu }\end{array}$ & AST & ALT & ALP & TPROT & ALB & LDH & AChE \\
\hline Evet & $20.1 \pm 12.2$ & $13.7 \pm 7.9$ & $69.8 \pm 25.4$ & $7.5 \pm 0.7$ & $4.2 \pm 0.5$ & $338.0 \pm 299.9$ & $9847.3 \pm 2326.6$ \\
Hayır & $16.7 \pm 8.1$ & $13.4 \pm 8.6$ & $75.1 \pm 28.2$ & $7.2 \pm 0.7$ & $4.2 \pm 0.4$ & $263.7 \pm 211.7$ & $9329.9 \pm 2295.5$ \\
\hline T Değeri & 2.235 & 0.248 & -1.215 & 2.388 & 0.617 & 1.947 & 1.411 \\
P Değeri & 0.027 & 0.804 & 0.226 & 0.018 & 0.538 & 0.053 & 0.160 \\
\hline
\end{tabular}

\section{Tartışma ve Sonuç}

Çalışmamız pestisit satılan yerde çalışan işçilerde çalışma süresi ile kolinesteraz seviyesinin azaldığını, karaciğer fonksiyon testlerinden AST'nin değişmediğini, ancak ALT'nin arttığını, ALP, TPROT, $A L B$ ve $L D H$ seviyelerinin azaldığını göstermiştir (Dökmeci ve Dökmeci, 2005). Her iki enzim de vücutta pek çok değişik dokuda bulunabilirken önemli kısımları karaciğerden salınır. ALT karaciğer hasarı için daha spesifik bir göstergesi olup (Sataloğlu ve ark., 2007) ALT'nin artması karaciğer hasarının olduğunu gösterir. TPROT ve ALB karaciğerin protein üretme kapasitesi ile ilgili fonksiyonlarını gösterir. Bu parametrelerdeki düşüş yine bir karaciğerin protein üretimine etki eden bir hasarın olduğunu gösterebilir (Eyer, 2003). ALB net olarak bilinmese de uzun süre pestisitlere maruziyetin TPROT seviyesinde azalmaya sebep olduğu bilinmektedir (Ghouri ve ark., 2010) . LDH karaciğer ve karaciğer dışında bulunan ve karaciğer fonksiyon testi olarak kullanılan bir enzim olup, seviyesindeki düşme yine yapımı ile ilgili bir defekte işaret edebilir (Garg ve ark., 2004). Pek çok pestisitin antioksidan defanstaki enzimlerin etkisini azalttı̆̆ı bilinmektedir. Yapılan çalışmalarda bazı pestisitlerin eritrositlerde AChE'ı ve antioksidan enzimleri azaltarak oksidasyonu arttırdığı gösterilmiştir (Santi ve ark., 2011). Kolinesteraz inhibisyonu, sinir sinapslarında ve nöromüsküler kavşaklarda ACh'nin artmasına yol açarak, ACh reseptörlerinin aşırı uyarılmasına neden olur. AChE inhibisyonuna özellikle organik fosforlu pestisitler yol açar (Saydam ve ark., 2006). Ortaya çıkan klinik bulguların önemli bir kısmı sinaptik aralıkta aşırı ACh birikimi sonucunda ortaya çıkan nikotinik ve muskarinik aktivite artışıdır (Sarıtaş ve ark., 2007). Çalışmamızda pestisit satış yerlerinde çalışma süresi ile ACh artışı tespit edilmiştir; en belirgin olarak 9 yıldan fazla çalışan işçilerde görülmüştür. Pestisitlerin özel muhafazalar içinde satılması yerine açık olarak satılması hem buharlaşma ve hem de hava hareketlerinin etkisi ile ortam havasına geçmesine neden olabilir. Pestisitlerin olumsuz etkilerinden kaçınmak için satış yerlerinde muhafazalı bir oda bulundurulması önemlidir. Sürekli ortada duran bu maddelerin havaya karışma olasılığı artar. Pestisitlere solunumla maruziyet sonrasında bazı problemlere sebep olabilir (Güngördü ve ark., 2013). Bu maddeleri satan ve depolayan yerlerde havalandırma havada asılı kalan partiküllerin uzaklaştırması açısından gereklidir (Aktar ve ark., 2009). Pestisit zehirlenmeleri, kandaki kolinesteraz düzeyi ölçülerek ortaya çıkarılabilir. Solunum zorlukları, öksürük, burun akıntısı, göğüste daralma, gözde yanma ve sulanma, uykusuzluk, dikkat dağılması gibi belirtiler Normalin \%20-25 altında olan enzim düzeylerinde meydana gelir (Akın ve ark., 1992). 
Yurdumuzda pek çok pestisit satılırken bunların, insana zararsız olduğu iddia edilmektedir. Ancak bilimsel olarak bu kimyasalların hem insan hem de çevre üzerinde çok zararlı etkileri olduğu kanıtlanmıştır. Buna göre sadece bu sektörde çalışanlara değil topluma da gerekli eğitimler verilmeli ve insanlar pestisitler konusunda bilgilendirilmelidirler (Özay ve Arslantaş, 2016). Yapılan bir diğer çalışmada ilaçlama sektöründe çalışanlar ile zehirlenme ön tanısı ile gelen kişilerde erken tanı amacıyla kolinesteraz seviyesine bakmanın önemi vurgulanmıştır. İlaçlama sektöründe çalışanlarda düzenli aralıklarla kolinesteraz seviyesinin ölçümünün tanımlanmış merkezlerce yapılması, konunun ehemmiyeti açısından gereklidir. Ayrıca bu kişilerde kolinesteraz seviyesine bakılması ekonomi ve iş yükü bakımından büyük önem taşımaktadır. Aksi taktirde uzun süreli maruziyetlerde önlem alınmazsa ciddi sonuçlar ortaya çıkabilmektedir (Yücesan ve ark., 2013). ABD'de kolinesteraz inhibitörü olan pestisitleri uygulayan tarım işçilerinin, işverenleri tarafından özel sağlık sigortası yaptırılarak periyodik olarak enzim seviyelerinin ölçülmesi ve kayıtların 7 yıl boyunca saklanması yasal zorunluluk olarak yapılmaktadır. 30 günlük periyotlar içinde 30 saat veya daha fazla bu pestisitleri uygulayan işçilerin enzim seviyesine bakmak ve sonuçlarına göre gerekli önlemleri almak işverenin sorumluluğu altındadır (Furman ve ark., 2010).

Pestisitler soluduğumuz havayla aldığımız besinlerle ya da başka yollarla karşılaştığımız kimyasallardır. Bundan kaçınamadığımıza göre en azından sağlığımızı korumak adına bu maddelerin insanların sağlığını tehdit etmeyecek miktarlarda olması gerekir. Bu da çeşitli önlemlerin alınması ve denetimlerinin düzenli yapılması şeklinde olur. Ülkemizde bu denetim mekanizmasının yetersiz olmasının yanı sıra mevcut mekanizma bile yeterince iyi çalıştırılamamaktadır (Yanıkoğlu ve ark., 2001). Pestisit satış bayilerinde satış yapanların, yasa gereği ziraat mühendisi, eczacı, ziraat teknisyeni veya bitki sağlığı ile ilgili dersleri alarak mezun olmuş kişiler olması zorunluyken sadece \%48-80'i bu koşulları sağlamaktadır. Satış yerlerinde hijyeni sağlamak için gerekli olan lavabo ve sabun, on işyerinden birinde mevcut bulunmamaktadır (Şimşek, 2016).

Tarım ilacı satış bayilerinde çalışanlar, çoğu zaman bilinçsizce yanlış işlemler yaparak kendi sağlıklarını ve toplum sağlığını tehlikeye atmaktadırlar. Bu kişilere periyodik olarak eğitimler verilmeli ve tarım ilaçları konusunda bilinçlendirilmelidirler. Bu bayiler de eczaneler gibi rutin denetimlere tabi tutulmalı; çalışma koşulları, satılan ürünler, iş yeri sağlığı ve güvenliği açısından incelenmelidir. Pestisitler de aynı ilaçlar gibi kontrole tabi reçetelerle verilmelidir. Gıda Tarım ve Hayvancılık Bakanlığı ile Sağlık Bakanlığı pestisitlerle alakalı yapılacak düzenlemelerde işbirliği yapmalı, pestisit üreten, satan bütün firmalar ve işyerleri denetlenmelidir (Babayiğit ve ark., 2014). Ülkemizde bütün pestisitleri kapsayacak şekilde, üretici firmaların teknik gelişmelere bağlı olarak Güvenlik Bilgi Formları (GBF)'nı hazırlaması, güncellemesi ve ilgili birimlere dağıtması zarureti yasal bir statüye kavuşturulmalıdır. Pestisitlerle doğrudan temasta olan tarım ilacı satış bayilerinde çalışanlar, periyodik olarak kan testlerinden geçirilip kolinesteraz düzeyleri sürekli kontrol altında tutulmalı, bu toksikolojik analizlerin belirli merkezlerde yapılması sağlanıp kayıtlar tutulmalı ve gerekli istatistikler yapılmalıdır. Bu sonuçlar izlenerek etkilenim sınırlarının aşılıp aşıımadığına bakılmalıdır. Normalin altındaki enzim düzeylerinde bir süre ortamdan uzak kalmaları sağlanmalı ve çalışma koşulları düzeltilmelidir. Pestisitler, kontrollü olarak depolanması, satılması ve kullanılması gereken kimyasallardır. Ayrıca pestisitlerin, çevreye ve halk sağlığına etkileri açısından bilimsel olarak incelemeler yapılmalı bunun yanı sıra bu inceleme ve araştırmalar da devlet tarafından desteklenmelidir.

\section{Teşekkür}

$\mathrm{Bu}$ çalışma Harran Üniversitesi Bilimsel Araştırma Projeleri Koordinatörlüğü (HÜBAK) tarafından desteklenmiştir (Proje No: 14057).

\section{Kaynaklar}

Akın G, Pekgöz E, Gökhun H, 1992: Karaciğer. Tertip matbaası, 90 .

Aktar W, Sengupta D, Chowdhury A, 2009: Impact of pesticides use in agriculture: Their benefits and hazards. Interdisciplinary toxicology, 2(1), 1-12.

Babayiğit MA, Tekbaş OF, Çetin H, 2014: Zararlılarla Mücadelede Kullanılan Pestisitlerin Halk Sağlığına Etkileri ve Korumaya Yönelik Önlemler. TAF Preventive Medicine Bulletin, 13, 5, 405-412.

Butinof M, Fernandez RA, Stimolo MI, Lantieri MJ, Blanco M, Machado AL, Franchini G, Díaz MDP, 2015: Pesticide exposure and health conditions of terrestrial pesticide applicators in Córdoba Province, Argentina. Cad Saúde Pública, 31, 3, 633.

Center For Global Issues. Churchville, VA. http://www.cfgi.org/ Erişim tarihi: 7 Aralık 2008.

Çömelekoğlu Ü, Mazmancı B, Arpacı A, 2000: Pestisitlerin kronik etkisine maruz kalan Tarım işçilerinde karaciğer fonksiyonlarının incelenmesi. Turk J Biol, 24, 461-466.

Demirdöğen $\quad C B, \quad 2010$ : Organofosfatlı pestisit zehirlenmeleri ve serum paraoksonaz1 (PON1) enziminin organofosfat metabolizmasındaki rolü. Türk Hijyen ve Deneysel Biyoloji Dergisi, 67, 2, 97112. 
Dökmeci i, Dökmeci AH, 2005: Toksikoloji zehirlenmelerde tanı ve tedavi. 4.baskı. Ankara: Nobel Matbaacilık, 582-607.

Eyer P, 2003: The role of oximes in the management of organophosphorus pesticide poisoning. Toxicol Rev, 22, 3,165-90.

Furman J, 2010: Cholinesterase Monitoring For Agricultural Pesticide Handlers. Guidelines for Health Care Providers in Washington State, U.S.A.

Garg UK, Pal AK, Jha, GJ, Jadhao SB, 2004: Pathophysiological effects of chronic toxicity with synthetic pyrethroid, organophosphate and chlorinated pesticides on bone health of broilerchicks. Toxicol Pathol, 32, 3, 364-9.

Ghouri N, Presss D, Sattar N, 2010: Liverenzymes, nonalcoholic fatty liver disease, and incident cardiovascular disease: an arrativere view and clinical perspective of prospective data. Hepatology, $52,3,1156-61$.

Güngördü A, Sireci N, Kücükbay $H$, Birhanli A, Ozmen, $M$, 2013: Evaluation of Invitro and invivo toxic effects of newly synthesized benzimidazole-based organophosphorus compounds. Ecotoxicolgy and Environmental Safety, 87, 23-32.

Miraglia M, Marvin HJ, Kleter GA, Battilani P, Brera C, Coni E, Cubadda F, Croci L, De Santis B, Dekkers S, Filippi L, Hutjes RW, Noordam MY, Pisante M, Piva G, Prandini A, Toti L, Van den Born GJ, Vespermann A, 2009: Climate change and food safety: An emerging issue with special focus on Europe. Food and Cheical Toxicoloy, 47, 5, 1000-1021.

Özay Ö, Arslantaş D, 2016: Pestisit Maruziyeti ve Nöropsikiyatrik Etkileri. Osmangazi Tıp Dergisi, 38(1), 42-48.

Ridgway RL, Tinney JC, Macgregor JT, Slater NJ, 1978: Pesticide use in agriculture. Environ Health Perspect, 27, 103-112.

Santi A, Menezes C, Duarte MM, Leitemperger J, Lopes T, Loro VL, 2011: Oxidative stres biomarkers and acetylcholine sterase activity in human erythrocytes exposed to clomazone (invitro). Interdiscip Toxicol, 4, 3,149-53.
Sarıtaş A, Çakır Z, Aslan Ş, 2007: Organofosfat ve karbamat zehirlenmeleri. The Eurasian J Med, 3, 9,55-9.

Sataloğlu N, Aydın B, Turla A, 2007: Pesticide Poisoning. TAF Prev Med Bull, 6, 3, 169-174.

Saydam CK, Sözmen B, Aslan LS, 2006: Organofosfor zehirlenmelerine yaklaşım. Türkiye Klinikleri J Med Sci, 26, 73-7.

Şimşek Z, 2016: Tarım Sektöründe Çalışan Sağlığı ve Güvenliği Açısından Pestisit Uygulamaları. Türkiye Klinikleri, J Vet Sci Pharmacol Toxicol-Special Topics, 2, 64-68.

Tülüce Y, Çelik i, 2002: Influence of somecommercial pesticides on human erythrocyte carbonic anhydrase enzymes (invitro). Yüzüncü Yıl Üniversitesi, Ziraat Fakültesi, Tarım Bilimleri Dergisi, 12, 1, 27-29.

Vural N, 2005: Toksikoloji, Ankara Üniversitesi Eczacılık Fakültesi Yayınları, No:73, Ankara

Wafa T, Nadia K, Amel N, Ikbal C, Insaf T, Asma K, Hedi MA, Mohamed H, 2013: Oxidativestress, hematological and biochemical alterations in farmers exposed to Pepticides. J Environ Sci Health $B, 48,12,1058-1069$.

WHO, 1992: Our planet, our health: Report of the WHO commission on health and environment. Geneva: World Health Organization.

Yanıkoğlu A, Kaya B, Şeker D, Gebizli H, 2001: Antalya örtüaltı tarımında pestisit kullanımı. Standart, 79.

Yücesan B, Kurt M, Sezen F, Subaşı SA., 2013: Illaçlama sektöründe çalışan işçiler ile zehirlenme şüphesi görülen hastaların kolinesteraz seviyelerinin belirlenmesi. Türk Hijyen Deneysel Biyoloji Dergisi, 70, 1, 7-14.

Zeren O, Dikmen N, Kumbur H, Taga S, 1998: icçel ilinde tarımsal kesimde çalışan kişilerin plazmalarında kolinesteraz aktivite değişiminin araştırılması. Türk Entomol Derg, 22, 3, 199-205.

*Yazışma Adresi: Fatma MUTLU

Harran Üniversitesi, Fen Bilimleri Enstitüsü,

Şanlıurfa, Türkiye.

e-mail: bilgesu06@mynet.com 